\title{
Analisa Kebutuhan Ruang Pandangan Bebas Pada Perlintasan Sebidang Tanpa Palang Pintu Di Desa Gelam, Kabupaten Sidoarjo
}

\author{
Nugroho Utomo \\ Program Studi Teknik Sipil \\ Universitas Pembangunan Nasional "Veteran" Jawa Timur \\ nugroho.ts@upnjatim.ac.id
}

\begin{abstract}
Railway crossing are amongst the most complex of road safety handling systems, due to the conflicts between road vehicles and rail infrastructure operations. Railway crossing until now is still become the one of major accident cause for road users. Mainly caused by indiscipline acts of road users when pass a railway crossing such as opening an illegal crossing, trespassing closed crossing gate and unaware road users. In the area that growing into an industrial and commercial area, the origins of road network that is local road type changed to collector road type. This roads transformation affected to appears of unprotected railway level crossings which existing railways and roads are closed to each other.

In Province of East Java especially at Sidoarjo Municipality there are two railway crossing which indicating to this serious matters located at JPL 69 Gelam 1 and JPL 70 Gelam 2. These two railway crossing showing an incomplete standard safety facilities which required such as railway warning sign and others. By this urgency, paperwork is held to discussing about standard safety facilities identifications and analyzing availability of clear visible zone according with Guidance of Technically Design of Railway Crossing. As a results explained that JPL 69 Gelam 1 is not recommended for safety reasons and JPL 70 Gelam 2 is recommended with several conditions that must be equipped.
\end{abstract}

Keywords: Railway crossing, road users, standard safety facilities, clear visible zone, Guidance of Technically Design of Railway Crossing

\section{ABSTRAK}

Perlintasan sebidang jalan kereta api adalah salah satu diantara pengaturan penanganan keselamatan jalan yang paling kompleks, ditinjau dari konflik terhadap operasi yang berlangsung di jalan raya dan jalan kereta api. Perlintasan sebidang antara jalan raya dan jalan kereta api hingga saat ini masih menjadi salah satu faktor penyebab kecelakaan bagi pengguna jalan. Disebabkan pengguna jalan masih tidak disiplin dalam melewati perlintasan, antara lain dengan membuka perlintasan liar, melanggar pintu yang sudah tertutup atau kurang hati-hati/ waspada dalam melewati perlintasan sebidang tersebut. Pada kawasan yang berkembang menjadi kawasan perdagangan atau industri, jaringan jalan yang semula berfungsi sebagai jalan lokal berubah menjadi jalan kolektor. Kondisi ini mempengaruhi terhadap keberadaan rel dan jalan raya yang berpotensi kecelakaan, yakni dengan adanya perlintasan kereta api yang tidak dijaga dan berdekatan satu dengan yang lain.

Pada Propinsi Jawa Timur khususnya di Kabupaten Sidoarjo terdapat dua perlintasan sebidang yang mengindikasikan permasalahan serius yakni terletak di JPL 69 Gelam 1 dan JPL 70 Gelam 2. Dua perlintasan sebidang ini menunjukkan fasilitas pengamanan standar yang tidak lengkap sesuai dengan persyaratan seperti rambu-rambu peringatan perlintasan kereta api dan lain sebagainya. Berdasarkan urgensi ini, penelitian ini dilakukan untuk membahas tentang identifikasi fasilitas pengamanan standar dan menganalisis ketersediaan ruang pandangan bebas menurut Pedoman Perencanaan Teknis Perlintasan Sebidang. Sebago hasil penelitian dijelaskan bahwa 


\section{JURNAL FORUM MEKANIKA}

Vol. 10, No. 1, Mei 2021, P-ISSN: 2356-1491, E-ISSN: 2655-8211

DOI: https://doi.org/10.33322/forummekanika.v10i1.1272

JPL 69 Gelam 1 tidak direkomendasikan dengan alasan keselamatan dan JPL 70 Gelam 2 direkomendasikan dengan beberapa persyaratan yang harus dipenuhi.

Kata kunci: perlintasan sebidang, pengguna jalan, fasilitas pengamanan standar, ruang pandangan bebas, Pedoman Teknis Perencanaan Perlintasan Sebidang 


\section{JURNAL FORUM MEKANIKA}

Vol. 10, No. 1, Mei 2021, P-ISSN: 2356-1491, E-ISSN: 2655-8211

DOI: https://doi.org/10.33322/forummekanika.v10i1.1272

\section{PENDAHULUAN}

Perlintasan sebidang antara jalan raya dan jalan kereta api hingga saat ini masih menjadi salah satu faktor penyebab kecelakaan bagi pengguna jalan. Disebabkan pengguna jalan masih tidak disiplin dalam melewati perlintasan, antara lain dengan membuka perlintasan liar, melanggar pintu yang sudah tertutup atau kurang hati-hati/ waspada dalam melewati perlintasan sebidang tersebut.

Pada kawasan yang berkembang menjadi kawasan perdagangan atau industri (industrial and commercial area), jaringan jalan yang semula berfungsi sebagai jalan lokal berubah menjadi jalan kolektor sehingga mempengaruhi terhadap keberadaan rel dan jalan raya yang berpotensi kecelakaan, yakni dengan adanya perlintasan kereta api yang tidak dijaga.

Di Propinsi Jawa Timur pada jalur kereta api lintas Surabaya - Malang saat ini terdapat 165 perlintasan sebidang. Dari 165 perlintasan sebidang tersebut yang dijaga baik oleh PT KAI dan swasta adalah sebanyak 93 perlintasan sedangkan sisanya sebanyak 67 perlintasan tidak dijaga dan 5 adalah perlintasan liar. Kecenderungan dari pengguna jalan adalah menerobos pada perlintasan yang dijaga maupun tidak dijaga. Telah banyak jatuh korban jiwa sia-sia akibat pelanggaran ini. Kebanyakan pengguna jalan menganggap bahwa keberadaan dari perlintasan jalan kereta api adalah mengganggu perjalanannya, sehingga tidak perlu ada prioritas untuk mengutamakan perjalanan kereta api. Pemahaman ini adalah sangat keliru sekali sebab telah diatur pada UndangUndang No. 13 Tahun 1992 pasal. 16: "Dalam hal terjadi perpotongan jalan kereta api dengan jalan yang digunakan untuk lalu lintas umum atau lalu lintas khusus, pengguna jalan wajib mendahulukan perjalanan kereta api" [1].

Kabupaten Sidoarjo berada pada lintasan jaringan jalan dan jaringan rel kereta api yang membentang dari arah utara ke selatan yakni jalur kereta api Surabaya - Malang antara lain melintasi Stasiun Waru, Stasiun Gedangan, Stasiun Sidoarjo, dan Stasiun Tanggulangin. Dari arah utara ke barat yakni jalur kereta api Surabaya - Madiun antara lain melintasi Stasiun Sepanjang, Stasiun Boharan, Stasiun Krian dan Stasiun Kedinding dan jalur percabangan (lintas tengah) yakni sebagai jalur shortcut yang menghubungkan Stasiun Sidoarjo dan Stasiun Tarik antara lain melintasi Stasiun Tulangan.

Kota Sidoarjo mempunyai banyak perlintasan sebidang disebabkan adanya perubahan tata guna lahan yang berhubungan dengan akses menuju kawasan yang berdekatan dengan lintasan kereta api terutama di jaringan rel yang berada di lintas utara - selatan yakni jalur kereta api Surabaya - Malang. Perlintasan sebidang di Kota Sidoarjo terutama terdapat pada daerah pemukiman dan daerah industri. Mengingat rapatnya jarak antar JPL (Jalan Perlintasan Kereta Api) di sepanjang jalur lintasan kereta api di Kota Sidoarjo terutama pada jalur lintasan kereta api Surabaya terlebih lagi ditambah dengan beberapa kondisi perlintasan sebidang yang tidak dilengkapi dengan fasilitas pengamanan standar seperti palang pintu tetapi hanya rambu-rambu peringatan saja. Permasalahan ini terdapat di JPL 69 dan 70 Gelam, Kecamatan Candi, Kabupaten Sidoarjo. JPL 69 dan 70 Gelam ini terhubung dengan jalan akses menuju pemukiman penduduk yang mempunyai karakteristik arus lalu lintas didominasi oleh sepeda motor. Karakteristik arus lalu lintas yang seperti ini menimbulkan kecenderungan pengguna jalan yang tidak disiplin terhadap mematuhi peraturan di perlintasan sebidang sehingga dapat membahayakan keselamatan jiwa dari pengguna jalan itu sendiri. Berdasarkan penelitian tentang perlintasan sebidang yang telah dilakukan oleh Aswad (2015) untuk mengetahui kondisi perlintasan sebidang, jumlah kecelakaan yang terjadi dan untuk merekomendasikan layak tidaknya perlintasan sebidang antara jalan kereta api dan jalan raya di wilayah Provinsi Sumatera Utara menurut Kepmenhub No.53 Tahun 2000 [2]. 


\section{JURNAL FORUM MEKANIKA}

Vol. 10, No. 1, Mei 2021, P-ISSN: 2356-1491, E-ISSN: 2655-8211

DOI: https://doi.org/10.33322/forummekanika.v10i1.1272

Oleh karena itu pada penelitian ini membahas tentang identifikasi fasilitas pengamanan dan ketersediaan ruang pandangan bebas atau kebutuhan zona aman pada perlintasan sebidang JPL 69 dan 70, Kecamatan Candi, Kabupaten Sidoarjo, Provinsi Jawa Timur. Selanjutnya dari penelitian ini dapat diketahui tentang hasil identifikasi fasilitas pengamanan dan kebutuhan ruang pandangan bebas pada lokasi studi menurut Peraturan Dirjen Perhubungan Darat No. SK.770/KA.401/DRJD/2005 tentang Pedoman Perencanaan Teknis Perlintasan Sebidang antara Jalan dengan Jalur Kereta Api.

\section{METODE/PERANCANGAN PENELITIAN}

\subsection{Perlintasan Sebidang}

Menurut Peraturan Dirjen Perhubungan Darat No. SK.770/KA.401/DRJD/2005 tentang Pedoman Perencanaan Teknis Perlintasan Sebidang antara Jalan dengan Jalur Kereta Api, perlintasan sebidang didefinisikan sebagai perpotongan sebidang atau pertemuan jalan kereta api dan jalan raya [3].

Berdasarkan waktu penggunaan perlintasan, kereta api menggunakan perlintasan dengan jadwal tertentu walaupun sering sekali tidak tepat waktu sedangkan kendaraan yang melewati persimpangan tidak terjadwal sehingga arus kendaraan dapat melintasi perlintasan kapan saja. Sehingga, pengaturan arus lalu lintas lebih kompleks dan situasional apabila dilaksanakan pada perlintasan sebidang antara jalan raya dengan jalan kereta api yakni melibatkan arus kendaraan bermotor pada bagian jalan raya dan arus kereta api pada jalan rel.

Ditinjau dari segi performa pergerakan dan sistem pengereman, kereta api merupakan moda transportasi yang mempunyai karakteristik operasi pergerakan yang berbeda dengan moda transportasi darat yang lain. Kereta api dalam operasi pergerakannya digabungkan dengan beberapa rangkaian kereta pengangkut penumpang atau barang, sehingga dalam proses pengeremannya tidak bisa sekaligus berhenti tetapi membutuhkan waktu sampai beberapa detik tergantung dari panjang pendek rangkaiannya. Apabila kereta api dihentikan secara mendadak maka akan menyebabkan kereta api beserta rangkaiannya menjadi berantakan dan terjadi kecelakaan. Dengan demikian jelaslah bahwa pada perlintasan kereta api dengan jalan raya diterapkan sistem prioritas untuk kereta api yakni arus kendaraan harus berhenti dahulu ketika kereta api melewati perlintasan [4].

\subsection{Fasilitas Pengamanan pada Perlintasan Sebidang}

Menurut Peraturan Dirjen Perhubungan Darat No. SK.770/KA.401/DRJD/2005 tentang Pedoman Perencanaan Teknis Perlintasan Sebidang antara Jalan dengan Jalur Kereta Api, pengaturan penempatan fasilitas pengamanan pada perlintasan sebidang yang tidak dilengkapi palang pintu serta yang tidak dijaga dijelaskan sebagai berikut :

1. Penempatan fasilitas pengamanan pada perlintasan sebidang di jalan dua lajur dua arah tidak terbagi yang tidak dilengkapi palang pintu dan tidak dijaga seperti ditunjukkan pada gambar 1 berikut: 


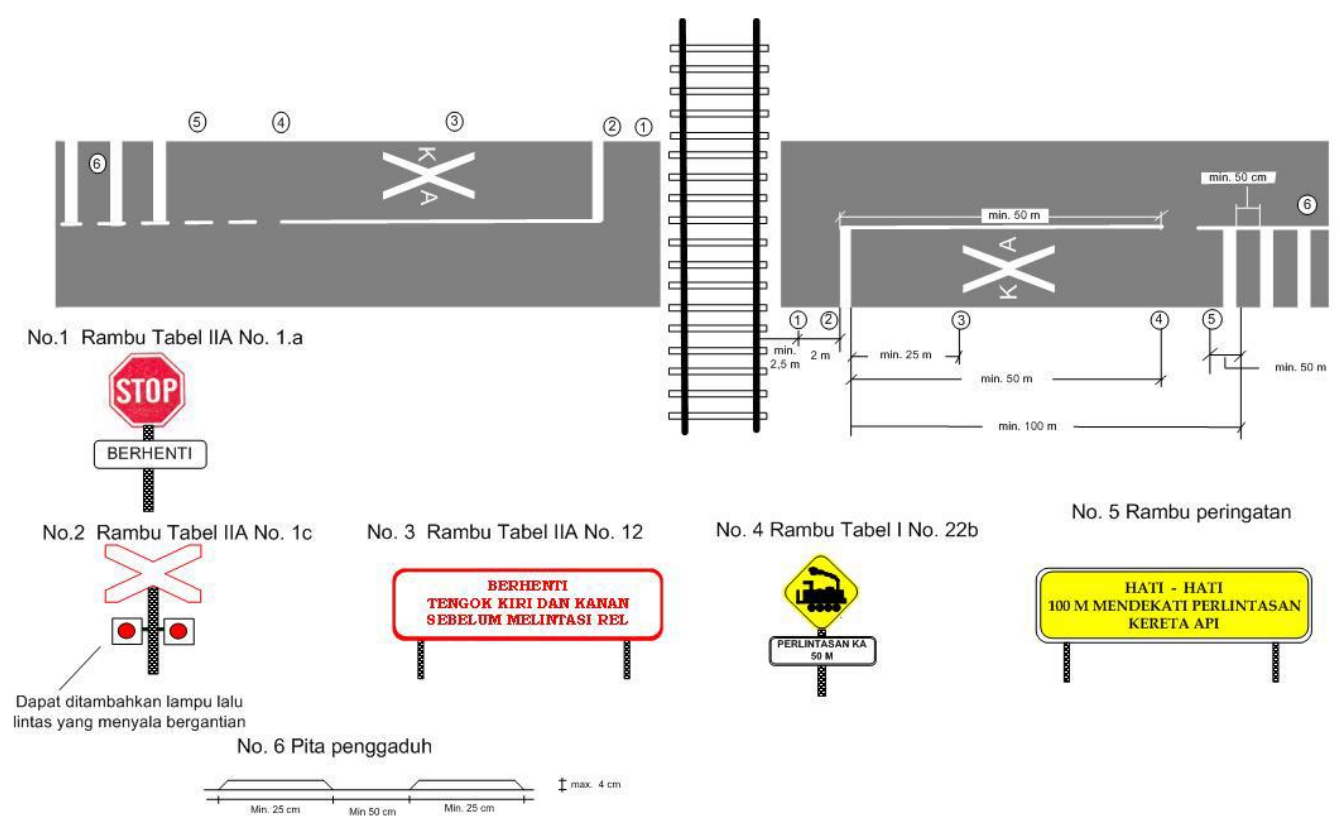

Gambar 1. Pemasangan rambu, marka dan perlengkapan lampu standar pada perlintasan sebidang yang tidak dilengkapi palang pintu dan tidak dijaga

\subsection{Ruang Pandangan Bebas}

Pada perlintasan sebidang antara jalan kereta api dan jalan raya harus tersedia ruang pandangan yang memenuhi syarat dan memadai.

Apabila tidak ada rambu-rambu atau tanda yang memberitahu bahwa akan ada kereta api yang melewati perlintasan, maka ada dua kondisi yang menentukan jarak pandangan, yakni [5]:

1. Kondisi saat kendaraan mendekati perlintasan sedemikian hingga kendaraan dapat melihat kereta api yang bergerak mendekati perlintasan, seperti ditunjukkan pada gambar 2 berikut:

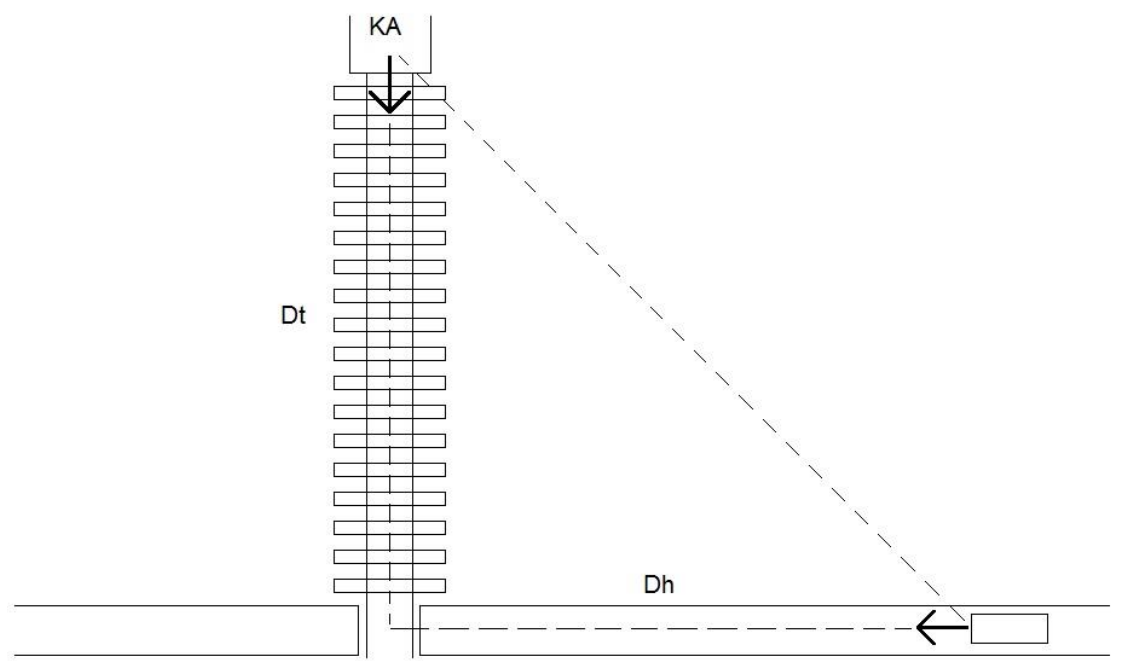

Gambar 2. Kondisi kendaraan ketika mendekati perlintasan sebidang sedemikian hingga kendaraan dapat melihat kereta api bergerak mendekati perlintasan 


\section{JURNAL FORUM MEKANIKA}

Dirumuskan sebagai berikut:

$$
\begin{aligned}
& \mathrm{Dh}=0,28 \cdot \mathrm{Vv} \cdot \mathrm{t}+\underset{254 \cdot \mathrm{f}}{\left(\underline{\mathrm{V}^{2}}\right)}+\mathrm{D}+\mathrm{d}_{\mathrm{e}} \\
& \mathrm{Dt}=\underset{\mathrm{Vv}}{(\mathrm{Vt})}\left(0,28 \cdot \mathrm{Vv} \cdot \mathrm{t}+\frac{\left(\mathrm{Vv}^{2}\right.}{254 \cdot f}+2 \mathrm{D}+\mathrm{L}+\mathrm{W}\right)
\end{aligned}
$$

dengan:

$\mathrm{Vv}=$ kecepatan kendaraan $(\mathrm{km} / \mathrm{jam})$

$\mathrm{Vt}=$ kecepatan kereta api $(\mathrm{km} / \mathrm{jam})$

$\mathrm{t}=$ waktu respons pengemudi $(2,5$ detik $)$

$\mathrm{f}=$ koefisien pengereman pada jalan

$\mathrm{Dh}=$ jarak pandang sepanjang jalan raya yang memungkinkan suatu kendaraan dengan kecepatan Vv melewati perlintasan dalam kondisi kereta api bergerak mendekati perlintasan

$\mathrm{D}=$ jarak antara ujung depan kendaraan dengan garis henti $(4,50 \mathrm{~m})$

$\mathrm{d}_{\mathrm{e}}=$ jarak antara bagian kabin pengemudi dengan ujung depan kendaraan $(1,60 \mathrm{~m})$

$\mathrm{L}=$ panjang keseluruhan dari kendaraan $(5,80 \mathrm{~m})$

$\mathrm{W}=$ jarak antara rel terluar, untuk single track diambil 1,50 m

$\mathrm{f}=$ koefisien pengereman pada jalan

menurut Direktorat Jenderal Bina Marga nilai

$\mathrm{f}=0,4-0,375$ untuk $\mathrm{Vv} \leq 40 \mathrm{~km} / \mathrm{jam}$

2. Kondisi saat kendaraan berhenti di depan perlintasan, seperti ditunjukkan pada gambar 3 berikut:

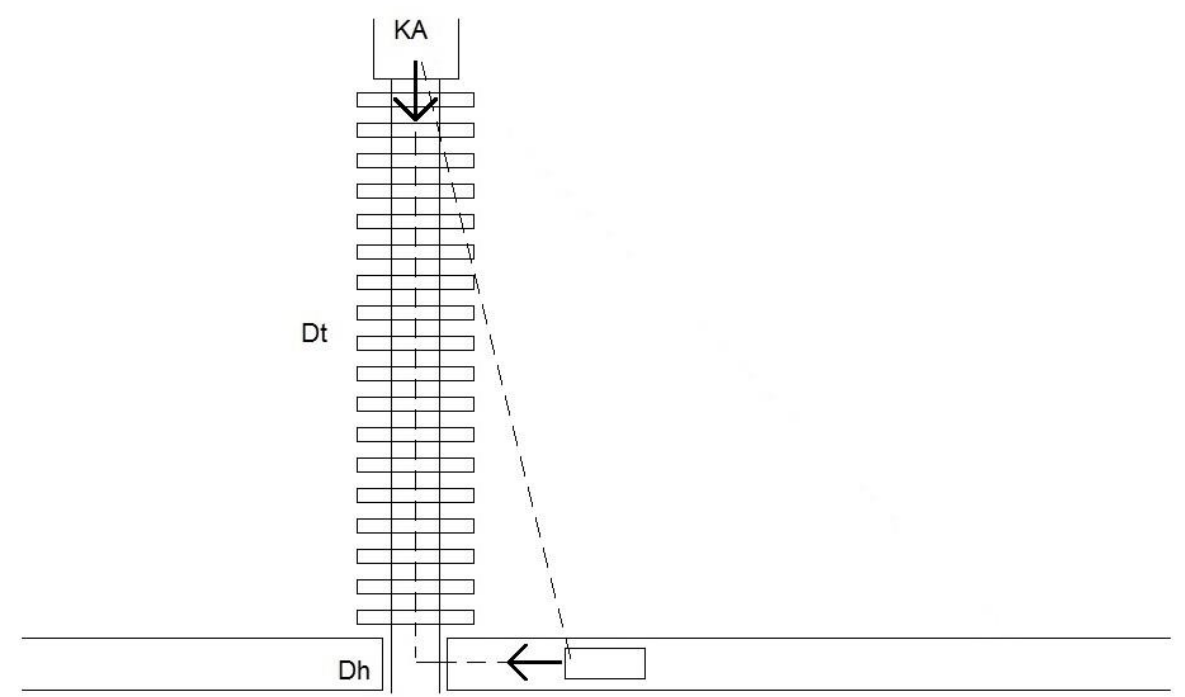

Gambar 3. Kondisi kendaraan ketika berhenti di depan perlintasan sebidang

Dirumuskan sebagai berikut:

$$
\mathrm{Dt}=0,28 \cdot \mathrm{Vt}\left(\left(\frac{\mathrm{V} 1}{\mathrm{a} 1}\right)+\frac{\left(\mathrm{L}+2 \mathrm{D}+\mathrm{W}-\mathrm{d}_{\mathrm{e}}\right)}{\mathrm{V} 1}+\mathrm{t}\right)
$$


dengan:

$\mathrm{Vt}=$ kecepatan kereta api $(\mathrm{km} / \mathrm{jam})$

$\mathrm{V} 1$ = kecepatan kendaraan saat akan melewati perlintasan $(\mathrm{km} / \mathrm{jam})$

a1 = percepatan kendaraan saat akan melewati perlintasan pada posisi gigi $1\left(0,45 \mathrm{~m} / \mathrm{dt}^{2}\right)$

$\mathrm{L}=$ panjang keseluruhan dari kendaraan $(5,80 \mathrm{~m})$

$\mathrm{W}=$ jarak antara rel terluar, untuk single track diambil 1,50 $\mathrm{m}$

$\mathrm{D}=$ jarak antara ujung depan kendaraan dengan garis henti $(4,50 \mathrm{~m})$

$\mathrm{d}_{\mathrm{e}}=$ jarak antara bagian kabin pengemudi dengan ujung depan kendaraan $(1,80 \mathrm{~m})$

$\mathrm{t}=$ waktu respons pengemudi $(2,5$ detik $)$

\section{HASIL DAN PEMBAHASAN}

Lokasi penelitian pada JPL 69 dan 70 di Kecamatan Gelam, Kabupaten Sidoarjo ditunjukkan pada gambar 4 berikut:

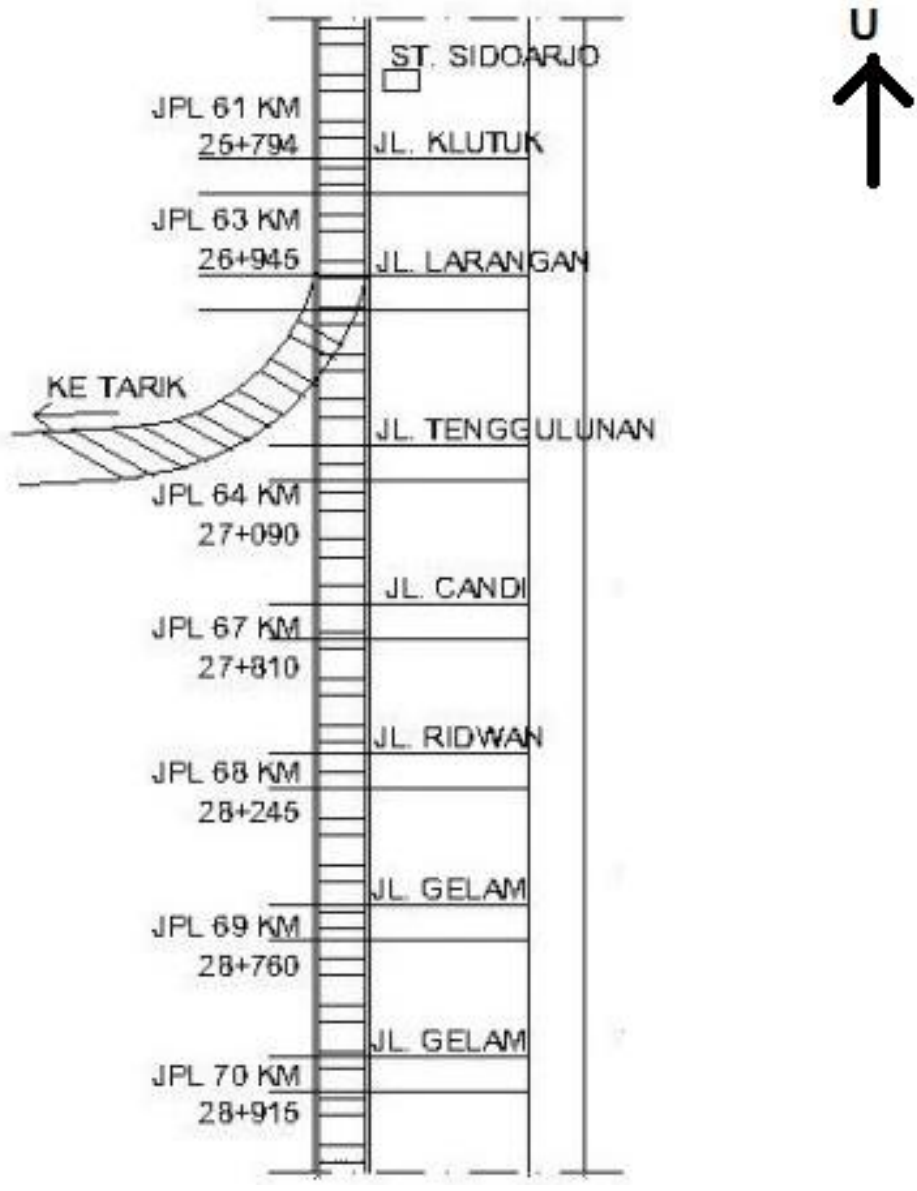

Gambar 4. Lokasi penelitian pada JPL 69 dan 70

Jalan yang berdekatan dengan JPL 69 adalah jalan lingkungan, yaitu jalan yang menghubungkan pemukiman dengan jalan lokal sekunder. Jalan lingkungan yang terdapat disini merupakan jalan dengan lebar efektif 2,80 m dan hanya dapat dilewati oleh kendaraan ringan dan sepeda motor secara satu arah saja. Untuk memudahkan proses identifikasi fasilitas pengamanan pada JPL 69 ditunjukkan pada gambar 5 berikut: 


\section{JURNAL FORUM MEKANIKA}

Vol. 10, No. 1, Mei 2021, P-ISSN: 2356-1491, E-ISSN: 2655-8211

DOI: https://doi.org/10.33322/forummekanika.v10i1.1272

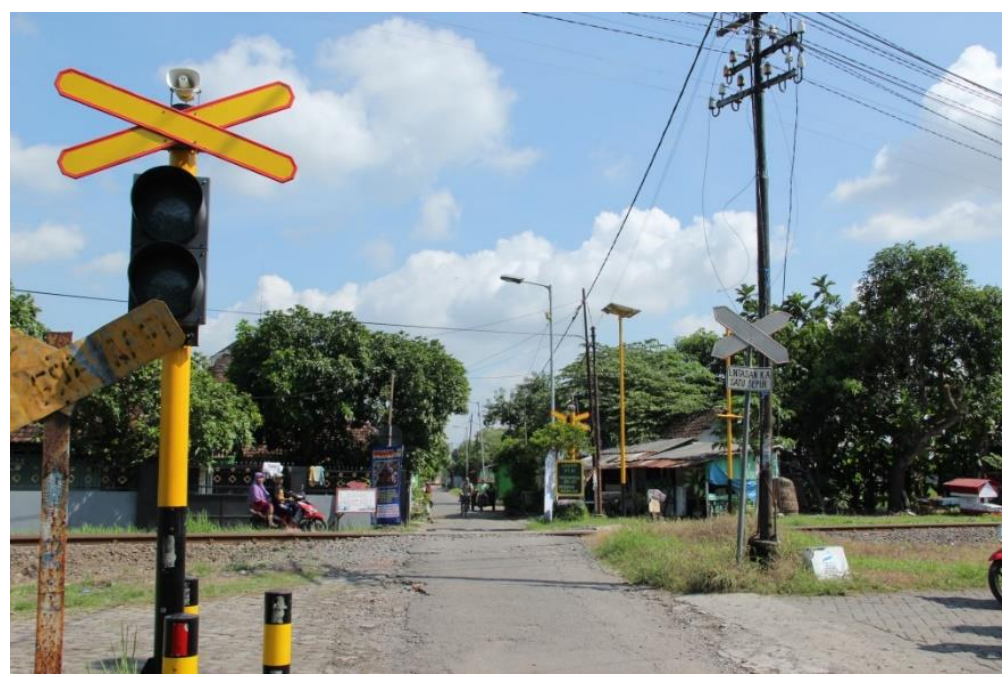

Gambar 5. Kondisi fasilitas pengamanan pada JPL 69 Jalan Gelam 1

Dari gambar 5 dapat diketahui bahwa kondisi fasilitas pengamanan pada JPL 69 Jalan Gelam 1 tidak sesuai dengan standar pengamanan pada perlintasan sebidang seperti yang ditunjukkan pada gambar 1. Sebagai hasil identifikasi pada JPL 69 adalah sebagai berikut:

a. Tidak terdapat marka jalan dan pita penggaduh (rumble strip) yang menunjukkan bahwa akan memasuki area perlintasan kereta api

b. Tidak terdapat rambu lalu lintas yang menyatakan berhenti

c. Tidak terdapat rambu peringatan yang menyatakan bahwa ada perlintasan kereta api

d. Tidak terdapat papan peringatan yang menyatakan bagi pengguna jalan untuk berhati-hati dalam melewati perlintasan kereta api

e. Tidak terdapat papan peringatan yang menyatakan bagi pengguna jalan untuk melakukan tindakan memastikan bahwa perlintasan sebidang adalah aman untuk dilewati

Sedangkan untuk memudahkan proses identifikasi fasilitas pengamanan pada JPL 70 ditunjukkan pada gambar 6 berikut:

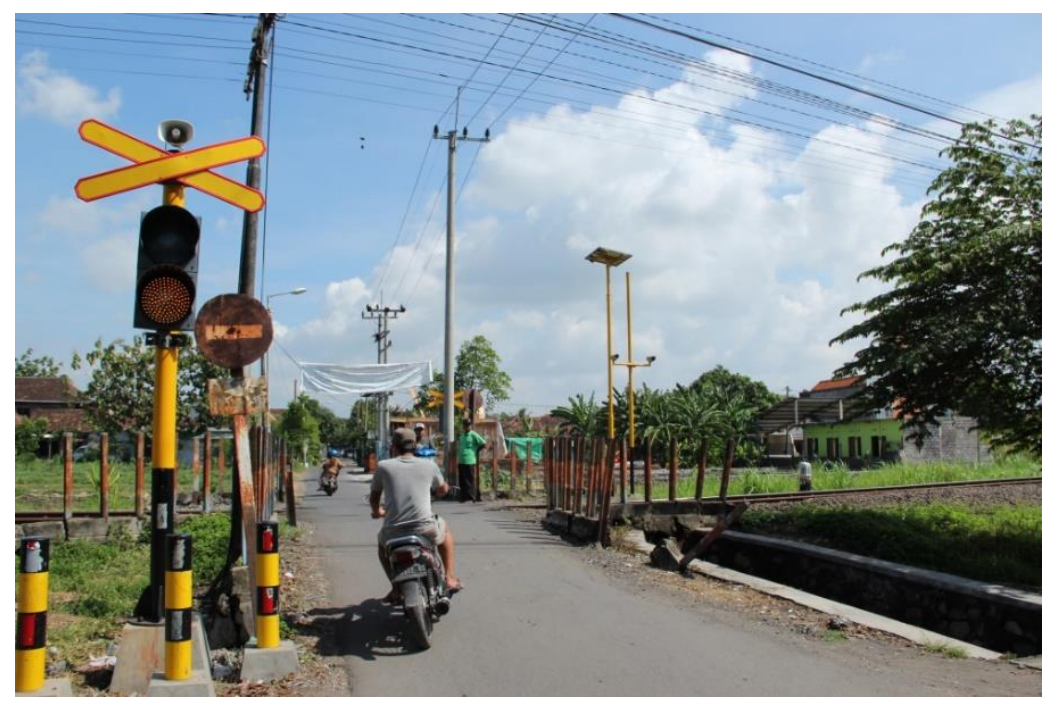

Gambar 6. Kondisi fasilitas pengamanan pada JPL 70 Jalan Gelam 2 
Dari gambar 6 dapat diketahui bahwa kondisi fasilitas pengamanan pada JPL 70 Jalan Gelam 2 tidak sesuai dengan standar pengamanan pada perlintasan sebidang seperti yang ditunjukkan pada gambar 1. Sebagai hasil identifikasi pada JPL 70 adalah sebagai berikut:

a. Tidak terdapat marka jalan yang menunjukkan bahwa akan memasuki area perlintasan kereta api

b. Tidak terdapat pita penggaduh (rumble strip) sebagai perangkat yang terpasang di permukaan jalan yang berfungsi untuk meningkatkan kewaspadaan pengguna jalan ketika akan memasuki perlintasan sebidang

c. Tidak terdapat rambu lalu lintas yang menyatakan berhenti

d. Tidak terdapat rambu peringatan yang menyatakan bahwa ada perlintasan kereta api

e. Tidak terdapat papan peringatan yang menyatakan bagi pengguna jalan untuk berhati-hati dalam melewati perlintasan kereta api

f. Tidak terdapat papan peringatan yang menyatakan bagi pengguna jalan untuk melakukan tindakan memastikan bahwa perlintasan sebidang adalah aman untuk dilewati.

Setelah melakukan identifikasi ketersediaan fasilitas pengamanan pada JPL 69 dan 70, maka langkah selanjutnya adalah melakukan analisa untuk menentukan kebutuhan ruang pandangan bebas pada JPL 69 dan 70.

Pada perlintasan sebidang antara jalan kereta api dan jalan raya ruang pandangan bebas yang memadai harus tersedia bagi dua pihak pelaku transportasi yakni kereta api dan kendaraan bermotor. Perlintasan sebidang kereta api dengan jangkauan pandangan arah lateral yang terbatas lebih berbahaya daripada perlintasan sebidang dengan jangkauan pandangan arah lateral yang tidak terbatas [6].

Untuk menghitung kebutuhan ruang pandangan bebas pada JPL 69, maka diperlukan informasi mengenai kondisi geometrik dari jalan yang berdekatan dengan JPL 69 dalam menentukan macam pendekatan penyelesaian. Dari gambar 5 tentang kondisi perlintasan sebidang di JPL 69 Jalan Gelam 1 diketahui bahwa pada sisi barat tidak terdapat ruang yang cukup dari pengguna jalan untuk dapat melihat secara langsung arah kereta api yang melintas karena terhalang oleh bangunan pemukiman setempat, maka pengguna jalan harus menghentikan kendaraannya di depan perlintasan. Sehingga untuk menghitung kebutuhan ruang pandangan bebas menggunakan pendekatan kondisi 2. Data lapangan yang diperoleh untuk mendukung perhitungan adalah:

a. Data kecepatan rata-rata kendaraan yang melewati perlintasan sebidang (V1): 28,54 $\mathrm{km} / \mathrm{jam}$

b. Data kecepatan rata-rata kereta api yang melintas (Vt) : 63,46 km/jam

Selanjutnya dapat dihitung nilai Dt untuk kondisi 2:

$\left.\mathrm{Dt}=0,28 . \mathrm{Vt}\left(\left(\frac{\mathrm{V} 1}{\mathrm{a} 1}\right)+\frac{\left(\mathrm{L}+2 \mathrm{D}+\mathrm{W}-\mathrm{d}_{\mathrm{e}}\right.}{\mathrm{V} 1}\right)+\mathrm{t}\right)$

dengan:

$\mathrm{Vt}=$ kecepatan kereta api $(\mathrm{km} / \mathrm{jam})$

$\mathrm{V} 1$ = kecepatan kendaraan saat akan melewati perlintasan $(\mathrm{km} / \mathrm{jam})$

a1 = percepatan kendaraan saat akan melewati perlintasan pada posisi gigi $1\left(0,45 \mathrm{~m} / \mathrm{dt}^{2}\right)$

$\mathrm{L}=$ panjang keseluruhan dari kendaraan $(5,80 \mathrm{~m})$ [7]

$\mathrm{W}=$ jarak antara rel terluar, untuk single track diambil $1,50 \mathrm{~m}$

$\mathrm{D}=$ jarak antara ujung depan kendaraan dengan garis henti $(4,50 \mathrm{~m})$ 


\section{JURNAL FORUM MEKANIKA}

Vol. 10, No. 1, Mei 2021, P-ISSN: 2356-1491, E-ISSN: 2655-8211

DOI: https://doi.org/10.33322/forummekanika.v10i1.1272

$\mathrm{d}_{\mathrm{e}}=$ jarak antara bagian kabin pengemudi dengan ujung depan kendaraan $(1,60 \mathrm{~m})$

$\mathrm{t}=$ waktu respons pengemudi $(2,5$ detik)

$\mathrm{Dt}=0,28 \cdot \mathrm{Vt}\left((\underline{\mathrm{V} 1})+\frac{\left(\mathrm{L}+2 \mathrm{D}+\mathrm{W}-\mathrm{d}_{\mathrm{e}}\right)}{\mathrm{a} 1}+\mathrm{t}\right)$
$\mathrm{Dt}=0,28.63,46\left(\frac{(28,54)}{0,45}+\frac{(5,80+2.4,50+1,50-1,60)}{28,54}+2,50\right)$

$\mathrm{Dt}=1180,51 \mathrm{~m}$

Dari hasil perhitungan diketahui bahwa Dh untuk kondisi 2 diambil sama dengan D yakni 4,50 $\mathrm{m}$ dan Dt adalah 1180,51 m artinya bahwa jarak kereta api menjelang perlintasan sebidang cukup jauh, karena kedatangan kereta api tidak bisa diamati secara langsung oleh pengguna jalan disebabkan terhalang oleh bangunan sehingga hal ini menimbulkan potensi kerawanan terhadap kejadian kecelakaan. Maka direkomendasikan perlintasan sebidang JPL 69 ini dapat ditutup dan dialihkan ke JPL 70 Jalan Gelam 2 dengan merencanakan frontage road.

Untuk menghitung kebutuhan ruang pandangan bebas pada JPL 70, maka diperlukan informasi mengenai kondisi geometrik dari jalan yang berdekatan dengan JPL 70 dalam menentukan macam pendekatan penyelesaian. Dari gambar 6 tentang kondisi perlintasan sebidang di JPL 70 Jalan Gelam 2 diketahui bahwa pada sisi barat dan timur terdapat ruang pandang bebas yang cukup dari pengguna jalan untuk dapat melihat secara langsung arah kereta api yang melintas.

Sehingga untuk menghitung kebutuhan ruang pandangan bebas menggunakan pendekatan kondisi 1.

Data lapangan yang diperoleh untuk mendukung perhitungan adalah:

a. Data kecepatan rata-rata kendaraan yang melewati perlintasan sebidang (Vv): 36,48 $\mathrm{km} / \mathrm{jam}$

b. Data kecepatan rata-rata kereta api yang melintas (Vt): $67,56 \mathrm{~km} / \mathrm{jam}$

Selanjutnya dapat dihitung nilai Dh dan Dt untuk kondisi 1:

$\mathrm{Dh}=0,28 \cdot \mathrm{Vv} \cdot \mathrm{t}+\left(\underline{\mathrm{Vv}^{2}}\right)+\mathrm{D}+\mathrm{d}_{\mathrm{e}}$

254.f

$\left.\mathrm{Dt}=\frac{(\mathrm{Vt})}{\mathrm{Vv}}\left(0,28 \cdot \mathrm{Vv} \cdot \mathrm{t}+\underset{254 \cdot \mathrm{f}}{\left(\mathrm{Vv}^{2}\right.}\right)+2 \mathrm{D}+\mathrm{L}+\mathrm{W}\right)$

dengan:

$\mathrm{Vv}=$ kecepatan kendaraan $(\mathrm{km} / \mathrm{jam})$

$\mathrm{Vt}=$ kecepatan kereta api $(\mathrm{km} / \mathrm{jam})$

$\mathrm{t}=$ waktu respons pengemudi (2,5 detik)

$\mathrm{Dh}=$ jarak pandang sepanjang jalan raya yang memungkinkan suatu kendaraan dengan kecepatan

$\mathrm{Vv}$ melewati perlintasan dalam kondisi kereta api bergerak mendekati perlintasan (m)

$\mathrm{D}=$ jarak antara ujung depan kendaraan dengan garis henti $(4,50 \mathrm{~m})$

$\mathrm{d}_{\mathrm{e}}=$ jarak antara bagian kabin pengemudi dengan ujung depan kendaraan $(1,60 \mathrm{~m})$

$\mathrm{L}=$ panjang keseluruhan dari kendaraan $(5,80 \mathrm{~m})$

$\mathrm{W}=$ jarak antara rel terluar, untuk single track diambil 1,50 m

$\mathrm{f}=$ koefisien pengereman pada jalan

menurut Direktorat Jenderal Bina Marga nilai

$\mathrm{f}=0,4-0,375$ untuk $\mathrm{Vv} \leq 40 \mathrm{~km} / \mathrm{jam}[8]$ 


$$
\begin{aligned}
& \mathrm{Dh}=0,28 \cdot \mathrm{Vv} \cdot \mathrm{t}+\left(\frac{\mathrm{Vv^{2 }}}{254 \cdot f}+\mathrm{D}+\mathrm{d}_{\mathrm{e}}\right. \\
& \mathrm{Dh}=0,28 \cdot 36,48 \cdot 2,50+\frac{\left(36,48^{2}\right.}{254 \cdot 0,4}+4,50+1,60
\end{aligned}
$$

$$
\begin{aligned}
& \mathrm{Dh}=44,73 \mathrm{~m} \\
& \mathrm{Dh} \approx 45 \mathrm{~m} \\
& \mathrm{Dt}=\frac{(\underline{\mathrm{Vt}})}{\mathrm{Vv}}\left(0,28 \cdot \mathrm{Vv} \cdot \mathrm{t}+\frac{\left(\mathrm{Vv}^{2}\right)}{254 \cdot \mathrm{f}}+2 \mathrm{D}+\mathrm{L}+\mathrm{W}\right) \\
& \mathrm{Dt}=\frac{(67,56)}{36,48}\left(0,28 \cdot 36,48 \cdot 2,50+\frac{\left(36,48^{2}\right)}{254 \cdot 0,4}+2 \cdot 4,50+5,80+1,50\right) \\
& \mathrm{Dt}=101,74 \mathrm{~m} \\
& \mathrm{Dt} \approx 102 \mathrm{~m}
\end{aligned}
$$

Dari hasil perhitungan diketahui bahwa Dh untuk kondisi 1 adalah $45 \mathrm{~m}$ dan Dt adalah 101,74 m. Artinya pada saat kecepatan kendaraan 36,48 km/jam akan melewati perlintasan sebidang harus melakukan persiapan berhenti sebelum perlintasan sejarak $45 \mathrm{~m}$ karena diperkirakan kereta api akan melewati perlintasan pada posisi sejauh $102 \mathrm{~m}$. Perlintasan sebidang JPL 70 ini mempunyai ruang pandang bebas yang cukup dari pengguna jalan untuk dapat melihat secara langsung arah kereta api yang melintas, maka direkomendasikan fasilitas pengamanan yang terdapat di JPL 70 dapat dilengkapi sesuai hasil identifikasi yakni:

a. Marka jalan yang menunjukkan bahwa akan memasuki area perlintasan kereta api

b. Pita penggaduh (rumble strip) sebagai perangkat yang terpasang di permukaan jalan yang berfungsi untuk meningkatkan kewaspadaan pengguna jalan ketika akan memasuki perlintasan sebidang

c. Rambu lalu lintas yang menyatakan berhenti

d. Rambu peringatan yang menyatakan bahwa ada perlintasan kereta api

e. Papan peringatan yang menyatakan bagi pengguna jalan untuk berhati-hati dalam melewati perlintasan kereta api

f. Papan peringatan yang menyatakan bagi pengguna jalan untuk melakukan tindakan memastikan bahwa perlintasan sebidang adalah aman untuk dilewati.

\section{KESIMPULAN DAN SARAN}

Sebagai kesimpulan dari penelitian ini adalah bahwa kondisi fasilitas pengamanan pada JPL 69 Jalan Gelam 1 tidak sesuai dengan standar pengamanan pada perlintasan sebidang adalah sebagai berikut:

a. Tidak terdapat marka jalan dan pita penggaduh (rumble strip) yang menunjukkan bahwa akan memasuki area perlintasan kereta api

b. Tidak terdapat rambu lalu lintas yang menyatakan berhenti

c. Tidak terdapat rambu peringatan yang menyatakan bahwa ada perlintasan kereta api

d. Tidak terdapat papan peringatan yang menyatakan bagi pengguna jalan untuk berhati-hati dalam melewati perlintasan kereta api 


\section{JURNAL FORUM MEKANIKA}

Vol. 10, No. 1, Mei 2021, P-ISSN: 2356-1491, E-ISSN: 2655-8211

DOI: https://doi.org/10.33322/forummekanika.v10i1.1272

e. Tidak terdapat papan peringatan yang menyatakan bagi pengguna jalan untuk melakukan tindakan memastikan bahwa perlintasan sebidang adalah aman untuk dilewati

Dari hasil perhitungan diketahui bahwa Dh untuk kondisi 2 diambil sama dengan D yakni 4,50 $\mathrm{m}$ dan Dt adalah 1180,51 m artinya bahwa jarak kereta api menjelang perlintasan sebidang cukup jauh, karena kedatangan kereta api tidak bisa diamati secara langsung oleh pengguna jalan disebabkan terhalang oleh bangunan sehingga hal ini menimbulkan potensi kerawanan terhadap kejadian kecelakaan. Maka direkomendasikan perlintasan sebidang JPL 69 ini dapat ditutup dan dialihkan ke JPL 70 Jalan Gelam 2 dengan merencanakan frontage road.

Sedangkan pada JPL 70 Jalan Gelam 2, dari hasil perhitungan diketahui bahwa Dh untuk kondisi 1 adalah $45 \mathrm{~m}$ dan Dt adalah 101,74 m. Artinya pada saat kecepatan kendaraan 36,48 $\mathrm{km} / \mathrm{jam}$ akan melewati perlintasan sebidang harus melakukan persiapan berhenti sebelum perlintasan sejarak $45 \mathrm{~m}$ karena diperkirakan kereta api akan melewati perlintasan pada posisi sejauh $102 \mathrm{~m}$. Perlintasan sebidang JPL 70 ini mempunyai ruang pandang bebas yang cukup dari pengguna jalan untuk dapat melihat secara langsung arah kereta api yang melintas, maka direkomendasikan fasilitas pengamanan yang terdapat di JPL 70 dapat dilengkapi sesuai hasil identifikasi yakni:

a. Marka jalan yang menunjukkan bahwa akan memasuki area perlintasan kereta api

b. Pita penggaduh (rumble strip) sebagai perangkat yang terpasang di permukaan jalan yang berfungsi untuk meningkatkan kewaspadaan pengguna jalan ketika akan memasuki perlintasan sebidang

c. Rambu lalu lintas yang menyatakan berhenti

d. Rambu peringatan yang menyatakan bahwa ada perlintasan kereta api

e. Papan peringatan yang menyatakan bagi pengguna jalan untuk berhati-hati dalam melewati perlintasan kereta api

f. Papan peringatan yang menyatakan bagi pengguna jalan untuk melakukan tindakan memastikan bahwa perlintasan sebidang adalah aman untuk dilewati.

\section{DAFTAR PUSTAKA}

[1] N. Utomo and I. Sholichin, "Determining Safety Distance of Road Users at Unprotected Railway Level Crossing (Case Study: Oro-Oro Ombo Wetan 1-2 Railway Level Crossings)," Proc. 2018 Int. Conf. Sci. Technol. (ICST 2018), pp. 45-49, 2018, [Online]. Available: http://eprints.upnjatim.ac.id/7977/1/Determining.pdf.

[2] Y. Aswad, "Studi Kelayakan Perlintasan Sebidang antara Jalan Kereta Api dengan Jalan Raya," Media Komun. Tek. Sipil, vol. 19, no. 2, pp. 183-189, 2015, doi: https://doi.org/10.14710/mkts.v19i2.8430.

[3] Direktorat Jenderal Perhubungan Darat, Pedoman Perencanaan Teknis Perlintasan Sebidang antara Jalan dengan Jalur Kereta Api. Indonesia: Departemen Perhubungan, 2005.

[4] Direktorat Jenderal Perhubungan Darat, Peraturan Pemerintah No.72 Tahun 2009 Tentang Lalu Lintas Angkutan Kereta Api. 2009.

[5] Direktorat Jenderal Prasarana Wilayah, Pedoman Perencanaan Perlintasan Jalan dengan Jalur Kereta Api. 2004.

[6] N. Ward and G. J. S. Wilde, "Driver approach behavior at an unprotected railway crossing before and after enhancement of lateral sight distances: An experimental investigation of a risk perception and behavioral compensation hypothesis," Saf. Sci., vol. 22, no. 1-3, pp. 6375, 1996. 
[7] Direktorat Jenderal Bina Marga, Tata Cara Perencanaan Geometrik Jalan Antar Kota. Indonesia, 1997.

[8] H. Saodang, Perencanaan Geometrik Jalan Raya, 1st ed. Bandung: Nova, 2009. 